The Canadian Society for Bioengineering

The Canadian society for engineering in agricultural,

food, environmental, and biological systems.

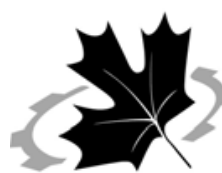

La Société Canadienne de Génie Agroalimentaire et de Bioingénierie

La société canadienne de génie agroalimentaire, de la bioingénierie et de l'environnement

Paper No. 06-107

\title{
Cost and Performance of Woody Biomass Size Reduction for Energy Production
}

\author{
Ladan J. Naimi, Shahab Sokhansanj, Sudhagar Mani, Mozammel Hoque, Tony Bi, \\ Department of Chemical \& Biological Engineering, University of British Columbia, 2360 \\ East Mall, Vancouver, BC V6T 1 Z3 Canada
}

\author{
Alvin R. Womac \\ Knoxville, TN USA

\section{Sundar Narayan} \\ First American Scientific Corporation, Delta, BC, V4G 1A6 Canada. \\ Written for presentation at the \\ CSBE/SCGAB 2006 Annual Conference \\ Edmonton Alberta \\ July 16 - 19, 2006
}

Department of Biosystems Engineering and Soil Science, University of Tennessee,

\begin{abstract}
Size reduction is often a first step in primary processing of biomass for its handling and downstream processing applications. Selecting appropriate equipment for size reduction has a very important role in the biomass preparation. One of the main reasons is that size reduction equipment consumes large quantities of power. In this paper, we reviewed commercial equipment used for size reduction of woody biomass. The review also included the capital cost, operating costs and performance of equipment. The performance of equipment is evaluated based on its power consumption and the quality of chip production, which includes average particle size and particle size distribution. The type of equipment used depends upon the end use of biomass. For pulping applications, woody biomass is chipped to a uniform size of $2.5 \mathrm{~cm} \times 5 \mathrm{~cm}$ (1in $\times$ 2in) with a thickness of $6 \mathrm{~mm}(1 / 4 \mathrm{in})$. For energy production, the size of biomass depends upon the type of burners used and it ranges from $6 \mathrm{~mm}(1 / 4 \mathrm{in})$ to $5 \mathrm{~cm}$ (2in). To distinguish between wood chips for pulping and ground material for energy production the word "hog fuels" is used. The

Papers presented before CSBE/SCGAB meetings are considered the property of the Society. In general, the Society reserves the right of first publication of such papers, in complete form; however, CSBE/SCGAB has no objections to publication, in condensed form, with credit to the Society and the author, in other publications prior to use in Society publications. Permission to publish a paper in full may be requested from the CSBE/SCGAB Secretary, PO Box 23101, RPO McGillivray, Winnipeg MB R3T 5S3 or contact bioeng@shaw.ca. The Society is not responsible for statements or opinions advanced in papers or discussions at its meetings.
\end{abstract}


quality requirements for wood chips are much more stringent than the quality requirement for hog fuel. Both wood chips and hog fuels need to be clean and as much as possible free from impurities (dirt). Cost of producing wood chip ranges from $\$ 161$ to $\$ 91 / \mathrm{h}$, where as cost of producing hog fuels range from 252 to $\$ 229 / \mathrm{h}$.

Keywords: chippers, hammer hogs, cost analysis, chipping mechanisms.

\section{Introduction}

Size reduction (Grinding) is one of the major pre-processing operations in using biomass as a source of energy or using it for producing pulp for paper industries. Grinders are the dominant machines in an energy wood harvesting system. They have the highest productivity and cost (Stocks et al 1987). Grinders use a wide range of energy (10-50 $\mathrm{kW} \mathrm{Mg}^{-1}$ ) depending on the material and grinding mechanisms (shear, impact, attrition). (Spinelli et al 2001). The design and choice of the grinder is important for reducing the energy input in preparing biomass. For pulping, the size and uniformity of chips are important quality characteristics and these can be achieved through a proper design and operation of a grinder (chipper).

When the grinding device is a knife, its geometry and the direction of the cut in relation to the work piece affects the configuration of the resulting chips, cutting power requirement and the quality of the chips surface (Hakkila, 1989). The productivity of a grinder when grinding biomass from forest is mostly time limited by the feeding process not the grinding itself. The objective of this paper is to review the performance of various commercial wood grinders with respect to ground quality and their cost estimation.

\section{Size reduction machinery classification}

There are many ways of classifying grinders. First one is according to the grinding mechanism. The basis of size reduction can be by splitting or shearing with sharp knives in which the geometry of particles are almost the same or by crushing or shredding with blunt impacting tools in which the particles are damaged due to compression.

In the case that the grinding mechanism is a cutting device it is called a chipper. The basic cutting device in chippers can be a disk to which cutting knives are attached or two horizontal high-speed drums with knives attached to them.

Disk chippers are the most popular chippers in pulp industries. In disk chippers straight knives are attached to a revolving heavy disk. The disk rotates at speeds that vary between 400-1000 rpm. Chippers can be in size range from whole log chipper of $350 \mathrm{~cm}(140 \mathrm{in})$ to $370 \mathrm{~cm}(150 \mathrm{in})$ in diameter with $1864.25 \mathrm{~kW}$ (2500hp) with direct coupled synchronous motors to $120 \mathrm{~cm}$ (48in) belt driven with 112 to $149 \mathrm{~kW}$ (150 to $200 \mathrm{hp}$ ) induction motors. The last one used for chipping waste wood in sawmills. Figure 1 shows a disk chipper. 


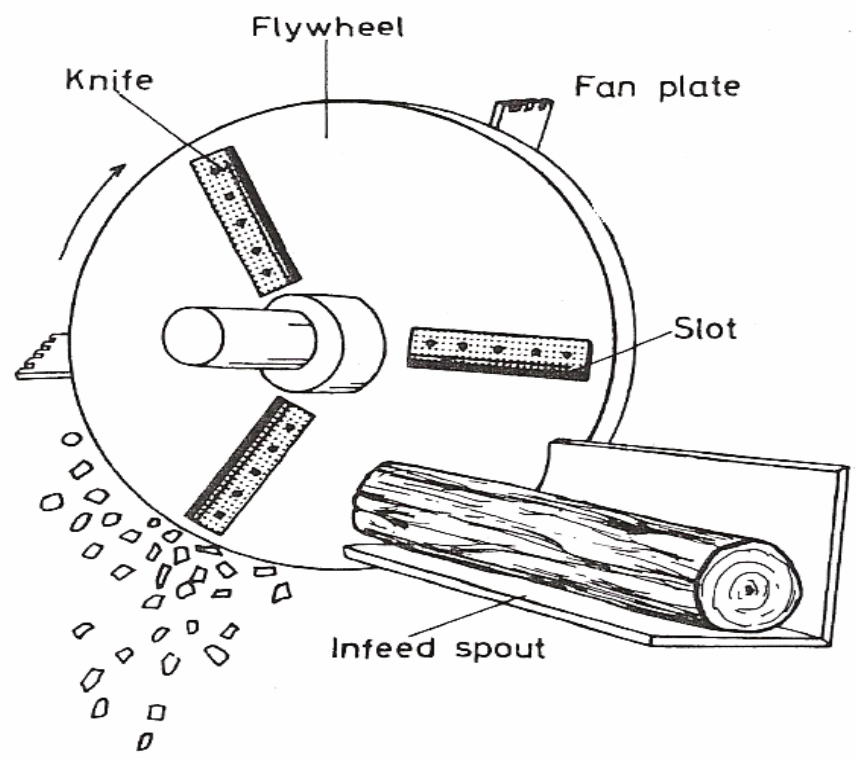

Figure 1. A disk chipper (Hakkila 1989)

The feeding of disc chippers can be in two different configurations, horizontal feed and gravity or drop spout feed (CWC, 1997). The process of chipping in disk chippers is controlled by:

- Adjusting the knife height or the anvil (the in-feed channel acts as anvil),

- The number of knives,

- The revolving speed of the disk,

- The in-feed speed,

In drum chippers, the knives are attached radially or spirally to a rotating cylinder. There are two ways of feeding in these chippers: the side-feed drum chippers or end-feed drum chippers. Figure 2-shows the principle of a cylindrical end-feed drum chipper. In comparison with disk chippers drum chippers are heavier and more expensive but the feeding process is easier. Drum chippers can handle a wider size range of raw material. The amount of oversized chips can be controlled by employing a basket screen on the bottom of the drum chipper.

V-drum chippers are a special model of drum chippers. They consist of two truncated cones attached together. The schematic of this chippers are also shown in Figure 2-b. V-drum chippers are loosing their role in size reduction machinery due to their high maintenance cost (CWC, 1997). 


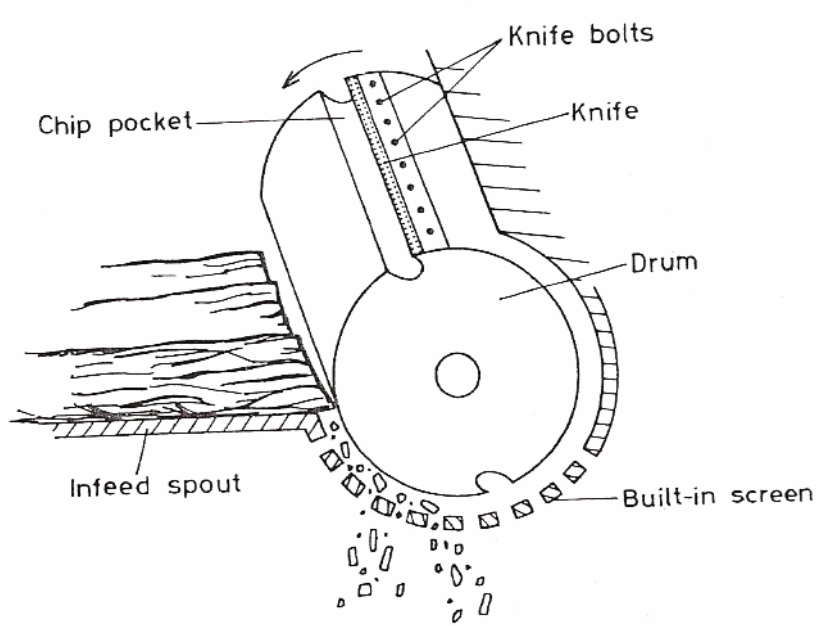

(a)

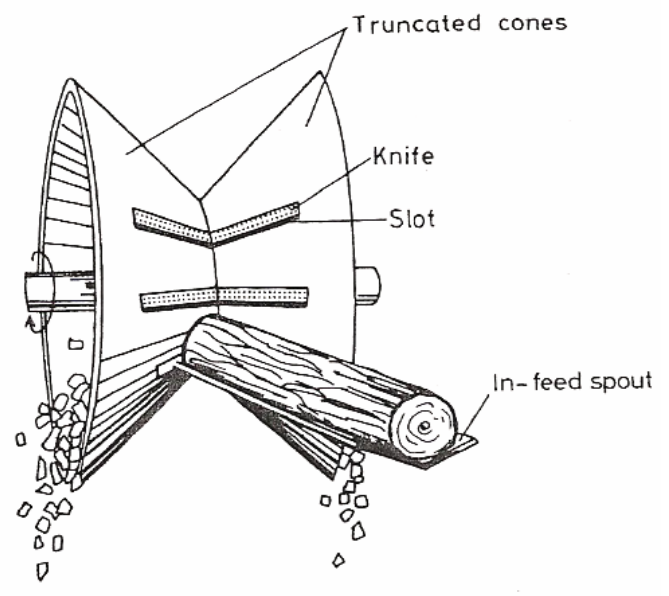

(b)

Figure 2. (a) The principle of a cylindrical end-feed drum chipper and (b) a V-drum chipper (Hakkila 1989).

Forest residues are always contaminated by sands and stones. These contaminates cause the sharp blades and knifes blunt. Avoiding this problem, the second group of size reduction machinery are hogs and hammermills which are based on hammering the biomass with blunt tools such as hammers. The produced grinds are damaged by compression, irregular shapes and wide size ranges. Figure 3 shows a hammermill hog. The size of the grind can be controlled by built-in screens (Hakkila 1998).

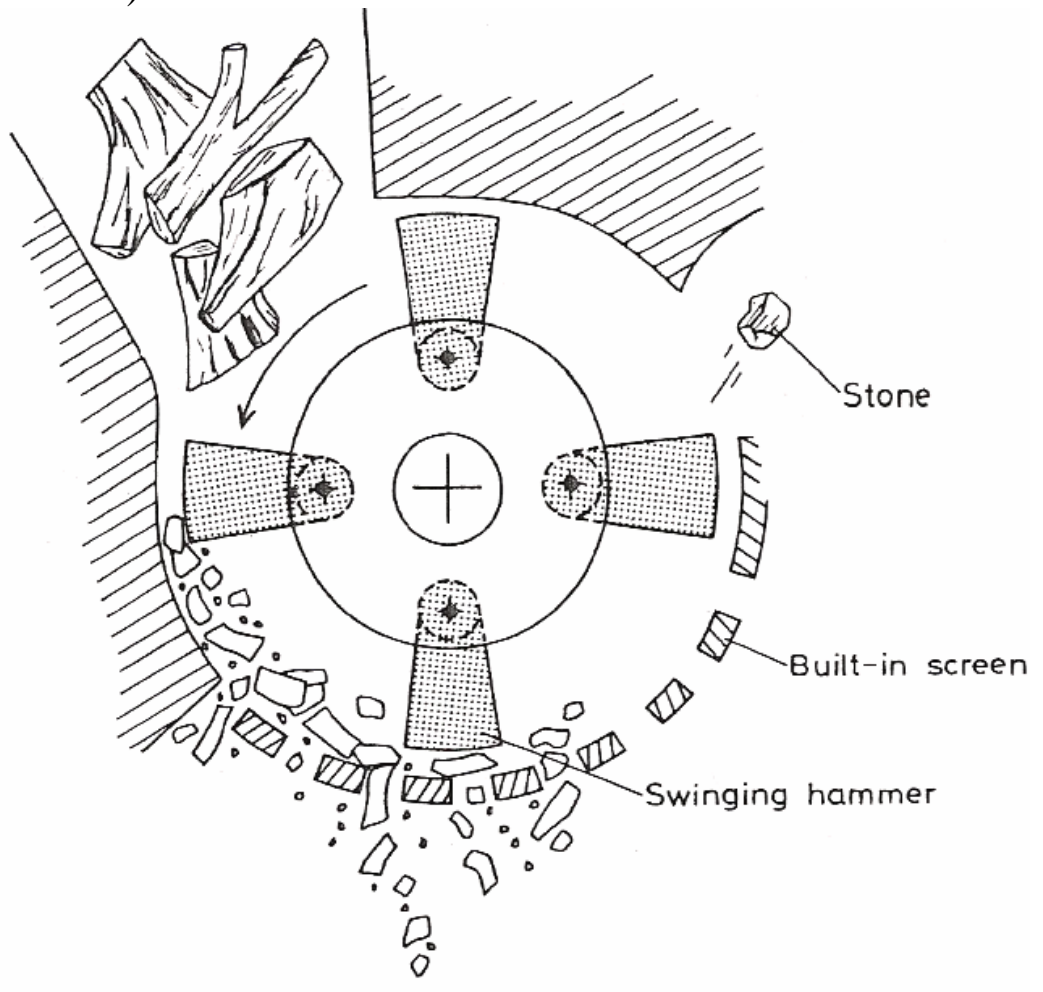

Figure 3. The principle of a hammer mill hog (Hakkila 1989). 
If the process of size reduction is divided to two stages, coarse grinding and fine grinding, hammermills will belong to the first category while the hammerhogs will belong to the second category. Hammermills are run a rotor speed two or three times faster than typical hog applications (up to $3600 \mathrm{rpm}$ ). They are used for making fine particles. Hogs have a $1200 \mathrm{rpm}$ limit and most of them rum in 700-900 rpm range. (CWC, 1997) There is no specified rule for calling them and in many articles they use the general name of hammermills for hogs too. Hammers in hammermills and hammer hogs can be fixed hammers or swing hammers. The swing hammers can accept more contaminated feed and they are easier to maintain in comparison with the fixed hammers that can get higher energy to the work piece.

There are a group of size reduction machinery that combines the two mechanisms of cutting and impact process (CWC, 1997). The ground material has a sharper and cleaner cutting surface and edge, like in chippers. At the same time they can process a high volume of material like hogs. An example of this group is rotary knife hammermill design. They are similar to hammer mills but instead of hammers the knives are mounted on the rotor. The knives are not as sharp as the knives in chippers. They can tolerate more contaminated materials in comparison with chippers but the more contaminated materials cause the more expensive operation and maintenance costs

Table 1 summarizes the reduction device, speed, feed stock, sensitivity to contaminants and the geometry of particles produced for different size reduction machineries. (CWC, 1997)

Table 1 . The summary of the size reduction device, speed, feed stock, sensitivity to contaminants and the geometry of particles produced for different size reduction machineries.

\begin{tabular}{|l|l|l|l|l|l|}
\hline Equipment & $\begin{array}{l}\text { Reduction } \\
\text { device }\end{array}$ & Speed & Feedstock & $\begin{array}{l}\text { Sensitivity to } \\
\text { contaminants }\end{array}$ & $\begin{array}{l}\text { Geometry of particles } \\
\text { produces }\end{array}$ \\
\hline Disk chipper & $\begin{array}{l}\text { Replacement } \\
\text { knives }\end{array}$ & High & $\begin{array}{l}\text { Whole log } \\
\text { Clean residue }\end{array}$ & High & Clean edge/two sided \\
\hline Drum chipper & $\begin{array}{l}\text { Replacement } \\
\text { knives }\end{array}$ & High & $\begin{array}{l}\text { Whole log } \\
\text { Clean residue }\end{array}$ & High & Clean edge/two sided \\
\hline $\begin{array}{l}\text { Swing hammer } \\
\text { hogs }\end{array}$ & $\begin{array}{l}\text { Swinging } \\
\text { hammers }\end{array}$ & Moderate & $\begin{array}{l}\text { Wood waste } \\
\text { Stumps }\end{array}$ & Low & Coarse/multi-surface \\
\hline $\begin{array}{l}\text { Fixed hammer } \\
\text { hogs }\end{array}$ & $\begin{array}{l}\text { Fixed } \\
\text { hammers }\end{array}$ & Moderate & $\begin{array}{l}\text { Wood waste } \\
\text { Stumps }\end{array}$ & Low & Coarse/multi-surface \\
\hline Knife Hogs & $\begin{array}{l}\text { Semi-sharp } \\
\text { hammers }\end{array}$ & Moderate & & Moderate & Semi-coarse \\
\hline
\end{tabular}

The word tub grinder is used many times when reviewing the size reduction machinery. They are basically hammer mills with a large tub designed to receive the bulk (woody) material. The rotor is placed at the bottom of the tub. It has free swinging hammers set between a series of disks.

The other group of size reduction machinery for wood is wood chunkers. Figure 4 shows three models of wood chunkers. They are spiral-head wood chunker, involuted disk chunker and a double involuted disk chunker. In comparison with wood chippers, the average size of ground material from wood chunkers is bigger than grinders. Chunk wood is defined as short, thick pieces of wood where the majority of particles have a relatively uniform length of $50-250 \mathrm{~mm}$ in the grain direction and a variable cross-section area, ranging from about finger size up to the diameter of the material reduced (Hakkila 1989). 


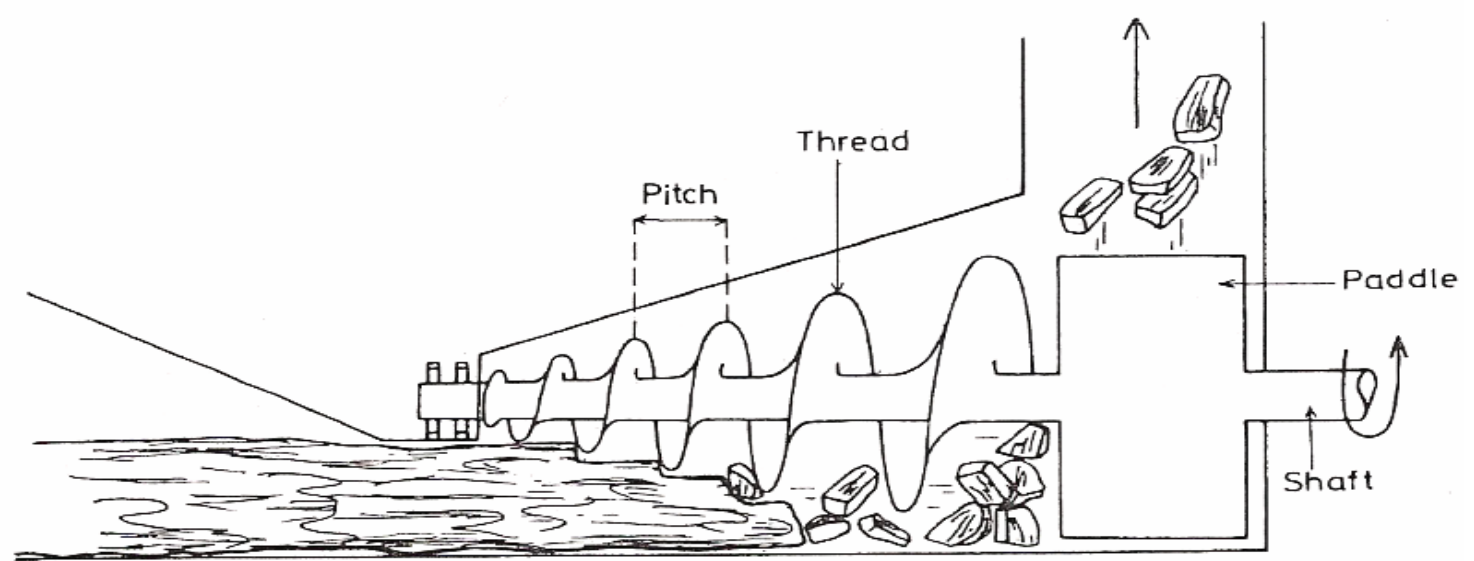

(a)

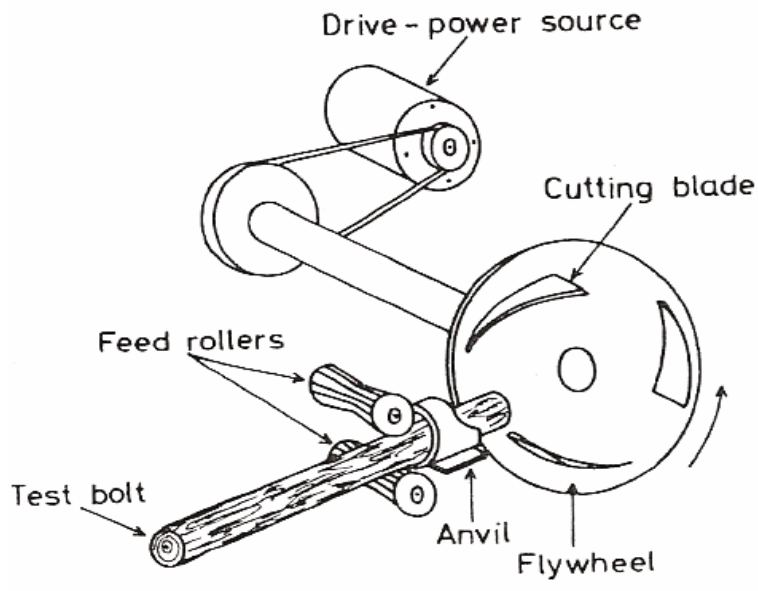

(b)

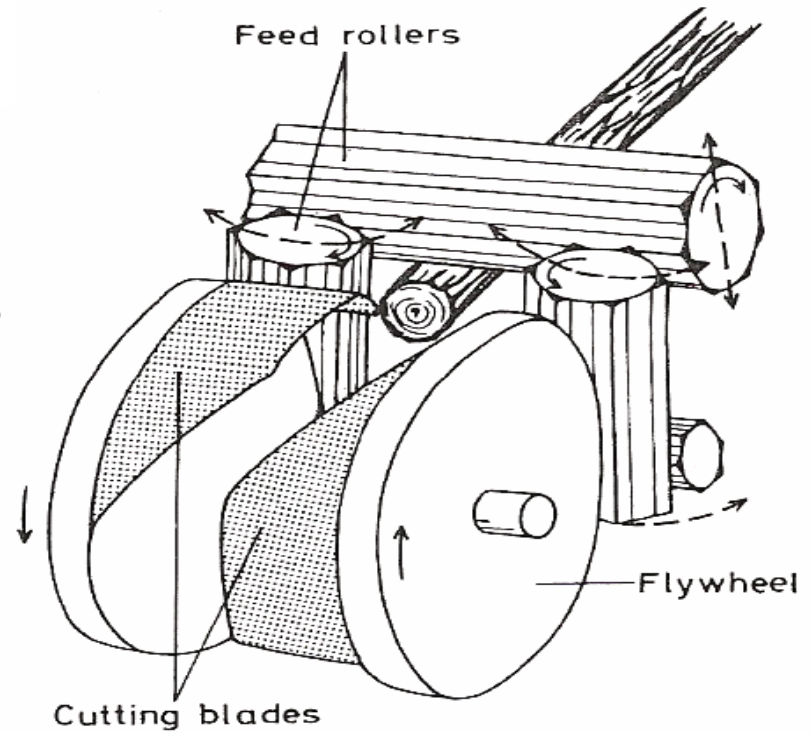

(c)

Figure 4. (a) A spiral-head wood chunker, (b) An involuted disk chunker and (c) A double involuted disk chunker. (Hakkila 1989)

The other classification of grinders is about whether they are portable or stationary. The portable grinders have relatively lower weight than stationary ones. The portable grinders have to be easily maintained in the processing place. As the feeding can't be uniform and is in different directions, the ground materials are in different particle length for portable grinders. For stationary grinders, the weight is not limited so the flywheel action is more and the revolution speed is higher than portable grinders.

Grinders can be classified due to where they operate (Hummel et. al. 1988). They may operate at landing, where the biomass is bunched already and a tractor driven grinder or a tractor mounted grinder is used for size reduction. It can be a stationary grinder which is not mobile on the site. They are large capacity machines and require hauling of the stems. They can be mounted on a truck or trailer with an auxiliary engine or be driven by the power-take-off driven tractor.

It can be a chip harvesting machine that cut the tree, grind and haul the ground material. They are heavy and powerful machines which are suitable for large-scale productions. 
When the grinders operate in the terrain, they have to be equipped with a chip container and have the ability of moving on different steep levels and stripe roads. But as the transporting and grinding are done by one machine the cost will be reduced and it makes the harvesting of biomass from small sites commercially doable. It can be a grinder-hauler. In this case they are either specialized machine or a combination of machines for grinding/hauling operations that consists of a tractor or forwarder, a grinder and a chip storage which can be discharged easily into a road container. The machine is designed to be mobile on the felling site and is equipped with a loader. It has a capacity of at least $25 \mathrm{~cm}$ in diameter and has a minimum power requirement of $90 \mathrm{~kW}$. In this case the grinder can be a disk or drum chipper with axial side feeding.

When the grinders are working at a plant, the grinding process is independent of trucking and so the mobile grinder can be replaced by a stationary heavy grinder. In which the control of the process is facilitated, the demand for labor is decreased and the control of quality of the chips produced is easier.

Another similar classification of grinders is for utilizing small diameter un-merchantable trees or residues left on site after harvesting. Profit from selling this biomass can pay a portion of high harvesting cost (Stockes et al 1987). In addition to being portable, stationary or mobile, the grinding process can be combined with other processes onsite. Two examples of these combined machines are:

Mobile grinder harvester-forwarder: Grinders are mounted on a rubber-tired or tracked carrier and they are equipped with feller and an on board container. It fells the small trees and slashes, grinded them and the chips are discharged to the container and when the container is full the grinder travel back to the landing and unload the chips.

Mobile grinder-forwarder: The grinder is mounted on a rubber-tired or tracked carrier. In this case the felled and bunched material grinded and discharged into an on-board container. When the container is filled, the grinder will travel back to the landing for unloading the container.

For the last two cases that the grinder is also a forwarder the productivity reduced due to the spent time for conveying the chips to the landing. It is totally depended on the distance for transporting the chips. Always there is trade off between large on board bin size and the need of strong frame structures and large power systems.

Usually the operator's priority to use different types of grinders depends on its cost, ease of operation and a kind of local people's experience. According to a survey that was done in Italy this priority is summarized in Table 2. (Spinelli et al 2001)

Table 2. The operator's priority for using grinders in Italy (Spinelli et al 2001)

\begin{tabular}{|l|l|}
\hline Type of grinder & Features \\
\hline 1.PTO- driven model & Low purchase prices, flexible use \\
\hline 2.Tractor driven & $\begin{array}{l}\text { Mobile, limited by the maximum power of } \\
\text { available tractor }\end{array}$ \\
\hline 3. Self powered towed machine & $\begin{array}{l}\text { Powerful engines, wheeled chassis, poor } \\
\text { mobility }\end{array}$ \\
\hline $\begin{array}{l}\text { 4.Self proplled } \\
\text { (they integrate chipper, power unit, prime } \\
\text { mover and loader) }\end{array}$ & $\begin{array}{l}\text { May be based on an all-terrain vehicle or a truck. } \\
\text { Poor flexibility }\end{array}$ \\
\hline
\end{tabular}




\section{Quality specification of wood particles after size reduction for energy conversion}

One of the main factors that affect the selection of the size reduction machinery is the quality of the ground material that is needed for the process they are produced for, the end use process. Each end use needs its own size distribution of ground material. Even pulp and paper industries are an end use process for the ground material. Size reduction plays an important role as a preparation process before the raw material goes trough the main process of pulping. Table 3 summarizes the quality of ground biomass which is needed for different burners in combustion and gasifier process (Badger 2002).

Table 3. Summary of wood fuel specifications by burner type (Badger, 2002)

\begin{tabular}{|c|c|c|c|c|c|c|c|c|}
\hline & $\begin{array}{l}\text { Pile } \\
\text { burners } \\
\text { (wet } \\
\text { cells) }\end{array}$ & $\begin{array}{l}\text { Thin-pile } \\
\text { Spreader- } \\
\text { stoker }\end{array}$ & $\begin{array}{l}\text { Under- } \\
\text { fire } \\
\text { Stokers }\end{array}$ & $\begin{array}{l}\text { Suspension, } \\
\text { cyclonic }\end{array}$ & $\begin{array}{l}\text { Suspension, } \\
\text { air } \\
\text { Spreader- } \\
\text { stoker }\end{array}$ & $\begin{array}{l}\text { FBCs } \\
\text { (Fluidized } \\
\text { bed } \\
\text { combustors) }\end{array}$ & $\begin{array}{l}\text { Gasifiers, } \\
\text { Fixed } \\
\text { bed }\end{array}$ & $\begin{array}{l}\text { Gasifiers, } \\
\text { FBG }\end{array}$ \\
\hline \multirow{2}{*}{$\begin{array}{l}\text { Device } \\
\text { size } \\
\text { range }\end{array}$} & $\begin{array}{l}\text { Up to } 40 \\
\mathrm{GW}_{\mathrm{t}}\end{array}$ & & & $\begin{array}{l}1.5 \mathrm{MW}-3 \\
\mathrm{GW}_{\mathrm{t}}\end{array}$ & & $\begin{array}{l}15-900 \\
\mathrm{MW}_{\mathrm{t}}\end{array}$ & $\begin{array}{l}17 \mathrm{MW}_{\mathrm{t}^{-}} \\
24 \mathrm{GW}_{\mathrm{t}}\end{array}$ & $\begin{array}{l}2.5-50 \\
\text { MW }_{t}\end{array}$ \\
\hline & $\begin{array}{l}\text { Virtually } \\
\text { any kind } \\
\text { except } \\
\text { wood } \\
\text { flour }\end{array}$ & $\begin{array}{l}\text { Sawdust, } \\
\text { non- } \\
\text { stringy } \\
\text { bark } \\
\text { Shavings, } \\
\text { end cuts, } \\
\text { chips and } \\
\text { chips } \\
\text { rejects, } \\
\text { hog fuel }\end{array}$ & $\begin{array}{l}\text { Sawdust, } \\
\text { Non- } \\
\text { stringy } \\
\text { bark } \\
\text { shavings, } \\
\text { chips, } \\
\text { hog fuel }\end{array}$ & $\begin{array}{l}\text { Sawdust, } \\
\text { non-stringy } \\
\text { bark, } \\
\text { shaving, } \\
\text { flour, } \\
\text { sander dust }\end{array}$ & $\begin{array}{l}\text { Sawdust, } \\
\text { non-stringy } \\
\text { bark, } \\
\text { shavings, } \\
\text { flour, } \\
\text { sander dust, } \\
\text { hog fuel }\end{array}$ & $\begin{array}{l}\text { Virtually } \\
\text { and kind } \\
\text { except } \\
\text { wood flour } \\
\text { and stringy } \\
\text { materials }\end{array}$ & $\begin{array}{l}\text { Chip, } \\
\text { hog fuel }\end{array}$ & $\begin{array}{l}\text { Virtually } \\
\text { any kind } \\
\text { except } \\
\text { wood } \\
\text { flour and } \\
\text { stringy } \\
\text { materials }\end{array}$ \\
\hline $\begin{array}{l}\text { Particle } \\
\text { size }\end{array}$ & $\begin{array}{l}\text { Limited } \\
\text { by grate } \\
\text { size and } \\
\text { feed } \\
\text { opening }\end{array}$ & $6-50 \mathrm{~mm}$ & $6-38 \mathrm{~mm}$ & $6 \mathrm{~mm}$ max & $6 \mathrm{~mm} \max$ & $50 \mathrm{~mm} \max$ & $\begin{array}{l}6- \\
100 \mathrm{~mm}\end{array}$ & $6-50 \mathrm{~mm}$ \\
\hline $\begin{array}{l}\text { Moisture } \\
\text { Content }\end{array}$ & $<65 \%$ & $10-50 \%$ & $10-30 \%$ & $<15 \%$ & $10 \%$ & $<60 \%$ & $<20 \%$ & $15-65 \%$ \\
\hline
\end{tabular}

The other important end use of ground biomass is the production of densified fuels such as pellets, cubes or briquettes. The specification and the particle size needed of the three mentioned densified form of biomass are summarized in Table 4 .

Table 4. The particle size needed for the production of three forms of densified biomass

\begin{tabular}{|l|l|l|l|l|}
\hline & $\begin{array}{l}\text { Particle size needed } \\
(\mathrm{mm})\end{array}$ & Overall shape & Dimension(mm) & Density $\left(\mathrm{kg} . \mathrm{m}^{-3}\right)$ \\
\hline Pellets & $<3.2$ & Cylindrical & $\begin{array}{l}\text { 4.8-19.1 Diameter } \\
\text { 12.7-25.4 Length }\end{array}$ & 700 \\
\hline Cubes $^{2}$ & $25-75$ Long & Square cross-sec & & $641-801$ \\
\hline Briquettes $^{2}$ & $6-8$ & Cylindrical & $\begin{array}{l}\text { 50-100 Diameter } \\
\text { 200-300 Length }\end{array}$ & 1000-1500 \\
\hline
\end{tabular}

1.Mani et. al. 2003

2.Samson et. al. 2005 
Ethanol production is another end use of biomass. According to US Patent No. 5677154 this process needs a size of $1-6 \mathrm{~mm}$ of ground biomass.

In pulp and paper industries, as an end use process for ground wood, chippers with sharp knives are use for size reduction. The chips from these chippers have relatively regular shapes and limited size variation. They have to be clean and free of any contaminants. It can be controlled by controlling length of time in the chipper, maintaining chipping quality and using a series of screening process (Goulding 1988). The length of these chips is from 5 to $30 \mathrm{~mm}$. The thickness of chips is very critical in Kraft pulping and its range is from 1.5-4mm but in sulfite pulping it has minor importance. According to Smook (1992) the ideal chip is usually considered to be about $20 \mathrm{~mm}$ long in the grain direction and 4-5 mm thick but all chips 10-30 mm long and 3-6 $\mathrm{mm}$ thick are prime materials for pulping.

The quality of wood particles depends on the grinder. Figure 5 shows the size distribution of three models of size reduction machinery that were studied by (Asikainen et. al. 1998).

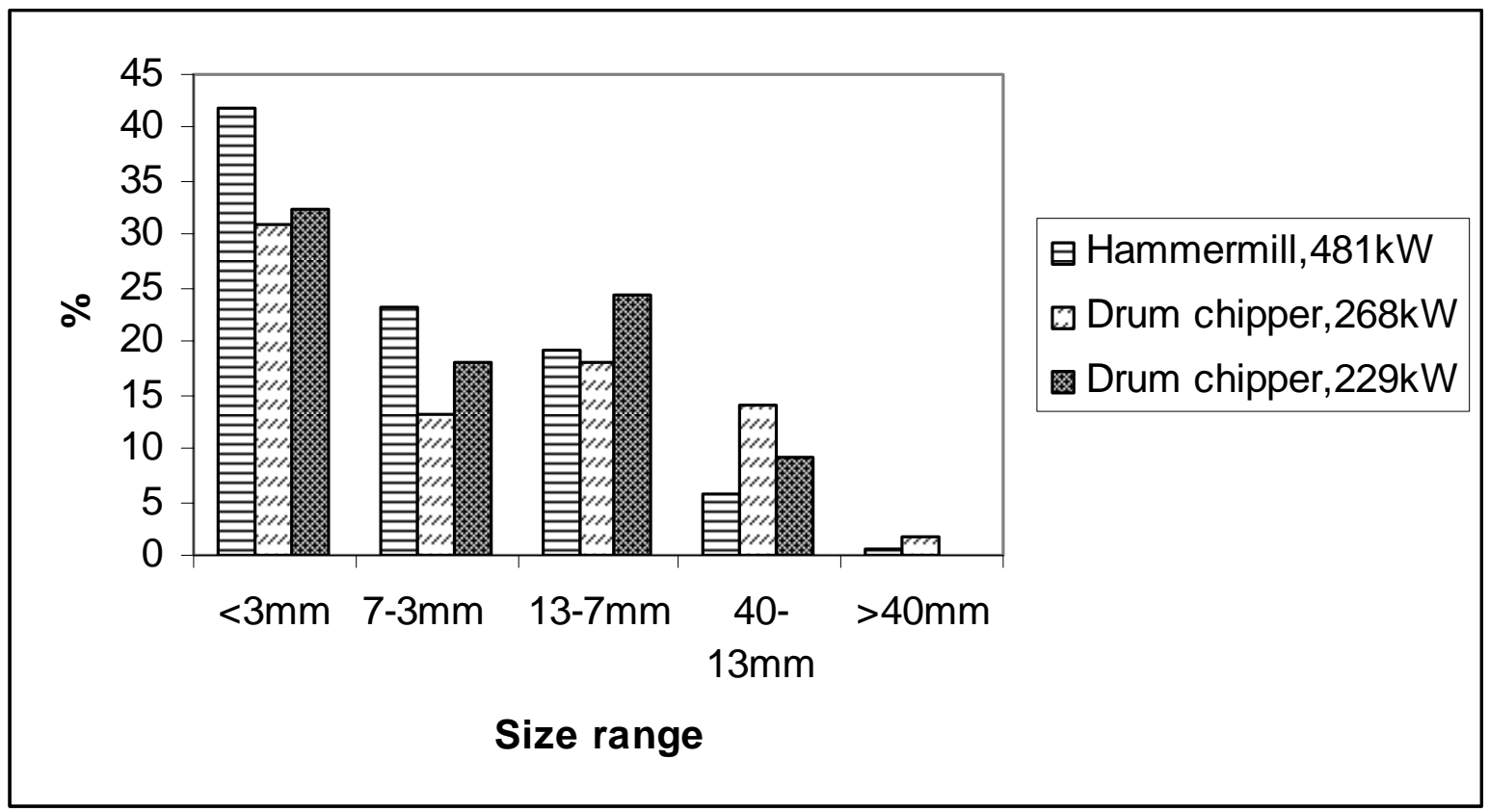

Figure 5. The size distribution of ground material for three grinder model (Asikainen et. al. 1998)

The grinder models are a drum chipper mounted on truck and the engine has an output of $267 \mathrm{~kW}$ (Evolution), a drum chipper mounted on an all-terrain truck bed that has a maximum output of 229kW(MOHA) and a hammermill crusher that its engine has an output of $481 \mathrm{~kW}$ (Morbark).

Figure 6 shows the different length distributions of the ground material from a cone-screw chipper chunker. The chipper has a set of six exchangeable conescrew knives. The quotient of the pitch length in mm and the number of threads is indicated below each set of length distributions. (Hakkila 1989) 
Figures 5 and 6 demonstrate the fact that by studying the quality of ground material from different models of size reduction machineries the selection of the model for each end use process will become easier.

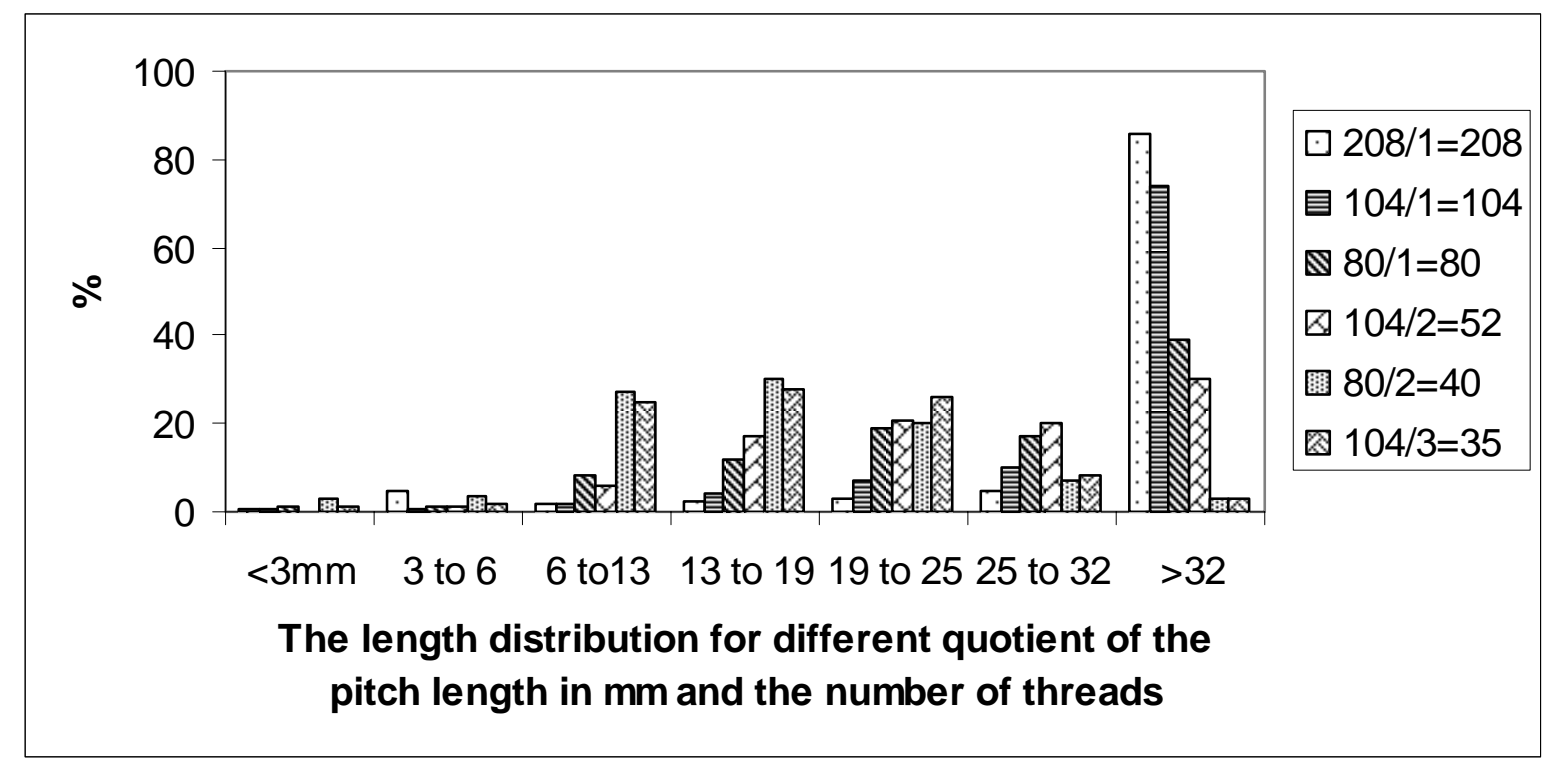

Figure 6. The length distribution of the ground material which are the product of a cone-screw chipper chunker with exchangeable cone-screw knives.

\section{Cost estimation of size reduction machineries}

Cost estimation for size reduction machineries is done based on Turhollow (2002) methodology. The methodology is summarized here. Capital recovery is calculated by equation 1.

Capital recovery $=\frac{(P P-d S V) * \frac{i(1+i)^{n}}{(1+i)^{n}-1}+d S V * i}{h_{a}}$

Where:

$\mathrm{PP}=$ Purchase price.

$\mathrm{dSV}=$ is the discounted salvage value which is calculated as the percent of list price at the end of year $n$ by : $60(0.885)^{\mathrm{n}}$.

$\mathrm{i} \quad=$ interest rate.

$\mathrm{n}=$ years of life.

$\mathrm{h}_{\mathrm{a}}=$ annual hours of use.

Repair and maintenance are calculated for chippers (drum chippers) 10 percent and for grinders (hammermills) 20percent of purchase price per year.

Fuel use is calculated by equation 2. Lubrication use is 15 percent of fuel use. The price of diesel is $2.85 \mathrm{USD} /$ gallon(average for 2005).

Fuel use ( gallons of diesel/hour $)=0.73 * 0.06 * 1.34 * \operatorname{Power}(\mathrm{kW})$ 
Insurance, housing and taxes are calculated by equation 3.

Insurance, housing and taxes $=\frac{(P P+d S V) / 2}{h_{a}} * i$

Labor cost is calculated by equation 4 . The benefit rate is assumed $\% 10$ and the wage rate is 20USD/hour.

Labor cost $=(1+$ benefit rate $) *$ wage rate

The operating inputs are charged for interest for six month basis as in equation 5.

Interest on operating cost $=(\mathrm{i} / 2) *($ repair and maintenance cost + fuel cost $)$

The total hourly cost is calculated as the summation of all the 6 above mentioned costs. Table 5 shows the economics of wood chips using different chippers and hammer hogs. Wood chip cost using drum chippers range from $\$ 161$ to $\$ 91 / \mathrm{h}$, whereas cost of size reduction using hammer hogs range from $\$ 252$ to $\$ 229 / \mathrm{h}$.

Table 5. A summary of cost estimation for size reduction machinery

\begin{tabular}{|l|l|l|l|l|l|l|}
\hline Model & $\begin{array}{l}\text { Power } \\
(\mathrm{kW})\end{array}$ & PP(US\$) & $\begin{array}{l}\text { Life time, } \\
\text { (year) }\end{array}$ & $\begin{array}{l}\text { Operating } \\
\text { hour, (h/y) }\end{array}$ & $\begin{array}{l}\text { Hourly cost } \\
(\mathrm{US} \$)\end{array}$ & $\begin{array}{l}\text { Reported cost }^{1} \\
\text { (US\$) }\end{array}$ \\
\hline Drum chipper & 200 & 625542 & 8 & 2000 & 157 & $118-212$ \\
\hline Small chipper & 186 & 187692 & 8 & 2000 & 91 & \\
\hline Medium chipper & 336 & 247436 & 8 & 2000 & 129 & \\
\hline Large chipper & 448 & 313589 & 8 & 2000 & 161 & \\
\hline $\begin{array}{l}\text { Mobile grinder } \\
\text { (not self propelled) }\end{array}$ & 521.5 & 381500 & 5 & 1700 & 229 & \\
\hline $\begin{array}{l}\text { Mobile grinder } \\
\text { Self propelled }\end{array}$ & 521.5 & 471500 & 5 & 1700 & 252 & \\
\hline
\end{tabular}

1. Desrochers, (1995)

\section{Conclusion}

The paper summarized various commercial scale size reduction units, chipping mechanisms and performance characteristics for the woody biomass. Almost all of the chippers work on the mechanism of shear cutting than impact action. Some types of hammer mills and crushers work on the mechanism of impact and/or shearing action. In overall, large size particles ( $>1$ ”) can be produced using drum or disk chippers and hammer hogs or tub grinders. Particles larger than 1" are most suitable for pulping or particle board production operations. Particles less than 1" can be obtained using hammer mills and are most suitable for energy production. Recently whole tree chippers are also used to the entire tree including branches and limbs and are further ground using hammer mill for energy production. Therefore, for energy production, two stages of size reduction are required for woody feedstocks (Fig. 7). Economic analysis of various size reduction units showed that hammer hogs are relatively expensive than chippers. Future research is directed to analyses the performance of hammer mills for woody biomass and its energy requirement during grinding. 


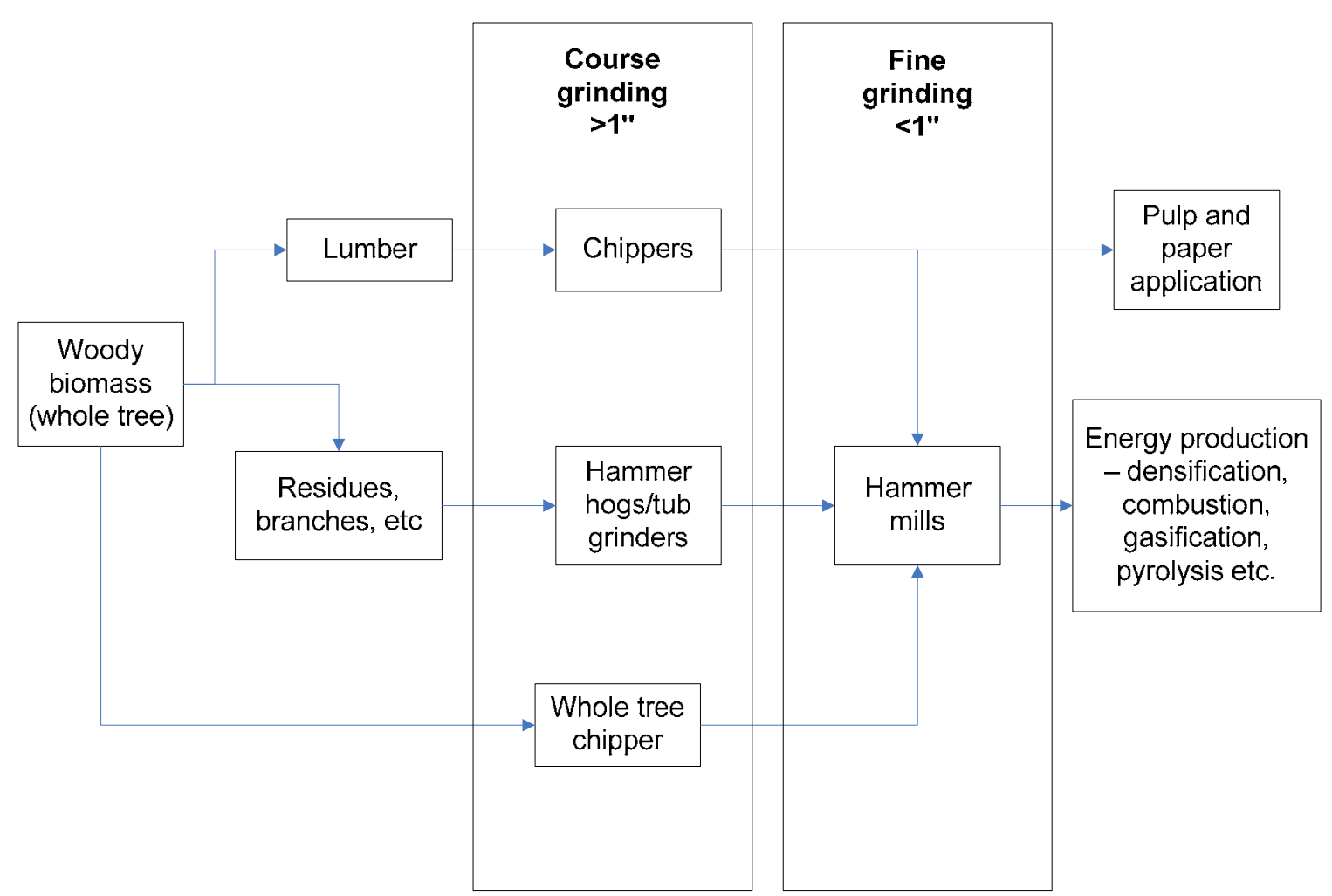

Figure 7. The two stage of size reduction process and its position in the whole process.

\section{References}

Asikainen, A. and P. Pulkkinen, 1998. Comminution of logging residues with evolution 910R chipper, MOHA chipper truck, and Morbark 1200 tub grinder. Journal of Forest Engineering, 9(1): 47-53

Badger, P.C., 2002. Processing cost analysis for biomass feedstocks Report No. ORNL/TM2002/199.

U.S. Department of Energy. Office of Energy Efficiency and Renewable Energy. Biomass Program.

CWC. 1997. Wood Waste Size Reduction Technology Study. Final report. Report No. CDL-973. Seattle, Washington. Available at http://www.p2pays.org/ref/13/12638.pdf Accessed on 200602-25.

Desrochers, L., D. Puttock, and M. Ryans 1995. Recovery of roadside residues using drum chippers. Technical Report No.TR-111, Vancouver, BC, Canada: Forest Engineering Research Institute of Canada (FERIC).

Goulding, C. J.,1988. Harvesting whole trees with processing and log allocation in the forest to conventional and energy products. IEA/Bioenergy Project A-1 Report No. 6. Rotorua, New Zealand. Forest Management and Resources Division, Forest Research Institute. 
Hakkila, P. 1989. Utilization of Residual Forest Biomass. Heidelberg, Berlin: Springer-Verlag

Hummel, F.C., Palz W. and G.Grassi. 1988. Biomass Forestry in Europe: A strategy for the Future. Essex, England: Elsevier Applied Science.

Mani, S., L. G. Tabil and S. Sokhansanj. 2003. An overview of compaction of biomass grinds. Powder Handling and Processing 15(2):160-168.

Samson, R., S. Mani, R. Boddey, S. Sokhansanj, D. Quesada, S. Urquiaga, V. Reis, C.H. Lem and C. Carpio. 2005. The potential of C4 perennial grasses for developing a global bio-heat industry. Critical Reviews in Plant Science, 24(5-6):461-495.

Smook, G. A.1992. Handbook for Pulp and Paper Technologists. Vancouver, BC : Angus Wilde Publications.

Spinelli, R. and B. Hartsough. 2001. A survey of Italian chipping operation. Biomass and Bioenergy 21:433-444

Stockes B. J., W. F. Watson, D. L. Sirois and R. K. Matthes. 1987. Factors Affecting Power Requirements for Chipping Whole Trees. Paper Number: 87-6012. ASAE Summer Meeting. Baltimore, Maryland.

Turhollow, A. 2002. Methodology for costing production and delivery options for energy crops. Bioenergy Feedstock Development Program. Oak Ridge National Laboratory.

Van Draanen, A. and S. Mello. 1997. Production of ethanol from biomass. U.S. Patent No. 5677154. 